\title{
Pluralisms and the Issue of the Third (trtīya)
}

\author{
Perry Schmidt-Leukel
}

Accepted: 25 February 2021/Published online: 11 April 2021

(C) The Author(s) 2021

In the past, all the major religious traditions, including their numerous branches and sub-traditions, have usually claimed their own unique superiority. ${ }^{1}$ Hence, contemporary efforts to conceive the relationship between religions in a pluralistic and egalitarian manner ${ }^{2}$ need to critically confront the specific doctrinal foundations on which the superiority-claim of their respective tradition rests. This implies that pluralist positions need to be developed in tradition-specific ways: as Hindu, Buddhist, Daoist, Jewish, Christian, Muslim, and so on, pluralisms. ${ }^{3}$ Moreover, a pluralist position articulated above or even against the existent religious traditions would be a performative self-contradiction: claiming a religious position uniquely superior to all religions. Therefore, tradition-specific pluralism also needs to show that, despite critiquing their tradition's superiority, they are nevertheless in line with some basic tenets of their tradition so that the pluralist position can be endorsed on the basis of such continuity. If pluralisms are tradition-specific in this dual sense of critique and continuity, the next step will be the dialogical exchange between various pluralists as part of an inter-religious theology and cross-cultural philosophy. For, whereas it is impossible for followers of different religions to

\footnotetext{
1 That "Hinduism" is no exception to this has been-ironically and despite frequent claims to the contrary-affirmed by the Ramakrishna Mission when it went to court in order to achieve the status of a minority religion (see Schmidt-Leukel 2017a: 65-66).

2 For my precise definition of "pluralism" as an option in the "theology of religions," see Schmidt-Leukel 2017b: 58-69.

3 See Schmidt-Leukel 2017a: 7-8.
}

Perry Schmidt-Leukel

perrys1@uni-muenster.de

Institute for Religious Studies and Inter-Faith Theology, Faculty of Protestant Theology, University of Muenster, Universitätsstraße 13-17, 48143 Muenster, Germany 
agree on their reciprocal (exclusivist or inclusivist) superiority claims (apart from agreeing to disagree), it is feasible for people of different faiths to agree on constitutive features of their pluralisms. ${ }^{4}$ Ayon Maharaj's Infinite Paths to Infinite Reality: Sri Ramakrishna and Cross-Cultural Philosophy of Religion (2018; henceforth, IPIR) is a very welcome contribution to this exciting and hitherto unprecedented exchange.

According to Maharaj, Rāmakṛ̣nna is not just a religious pluralist (affirming that major traditions such as "Christianity, Islam, Hinduism,.... and Buddhism have equal and maximal salvific efficacy" (IPIR 97), but one who "provides the foundation for a highly robust model of religious pluralism" (IPIR 100) or a "full-blown religious pluralism" (IPIR 81 and passim) surpassing some other pluralist positions, especially that of John Hick. In what follows, I will engage with Maharaj's claims by asking first how pluralistic Rāmakṛnna ${ }^{5}$ is, second whether or not Rāmakṛ̣ṇa's approach is essentially different from and superior to Hick's, and third what the appropriate foundation for the development of pluralisms should be.

Although Rāmakrșna holds that religions with a personal conception of the ultimate and those with an impersonal one are soteriologically on a par, they are not necessarily so epistemologically (IPIR 7, 36-37, 88, 106-7). "Both theistic and nontheistic spiritual paths have equal salvific efficacy" (IPIR 44), even if they falsely (!) assume that the divine is ultimately either a personal or an impersonal reality. Does Rāmakrṣna's claim that personal and impersonal aspects of the "Infinite Reality are equally real" (IPIR 44) imply epistemological superiority for his own teachings? Well, it certainly does. But any religious pluralist implies that the pluralist interpretation of religious diversity is epistemologically superior to an exclusivist or inclusivist (or naturalist) interpretation. The crucial issue is whether Rāmakṛṣna claims that his allegedly superior understanding of the ultimate is unique to his "Vijñāna Vedānta" and unavailable to people from other religious traditions. For this would make him a kind of primus-inter-pares pluralist, and thus, at the end of the day, an inclusivist.

Such an inclusivist reading of Rāmakṛ̣na would find prima facie support in his use of the ancient (originally either Jain or Buddhist) parable of the blind-born men and the elephant: While the blind ones (the followers of other paths?) grasp only some parts of the elephant, the vijñann $\bar{l}$ with her/his healthy eyes "can see the elephant as a whole" (IPIR 92). Yet Rāmakrṣna makes a crucial caveat, rendered by Maharaj as "since God is infinite, even the vijñanni cannot realize the whole of God" (IPIR 93; emphasis in the original), or, in Rāmakṛnna's own words, "God is with form, without form, and much more besides" (IPIR 35). What is the meaning of the clause "and much more besides"? Can there be any third between or beyond form (saguna) and non-form (nirguna)? While in the Vedāntic tradition a crucial discussion concerned the mysterious nature of the turiya (the "fourth" state of consciousness as distinct from waking consciousness, dream, and deep sleep), the crucial question to be raised in relation to Rāmakṛṇa is the issue of the "third" (trtizya). Can we understand this "much more besides" in an apophatic way, so that

\footnotetext{
${ }^{4}$ See Schmidt-Leukel 2017a: 109-29.

5 I have not done (much) independent research on Rāmakrșnna. So what I say here refers to Maharaj’s presentation and interpretation of Rāmakṛṣna.
} 
both "form" and "non-form" are human conceptual categories that do not apply to the true nature of the Infinite Reality being always "infinitely more" than any "particular form or aspect" (IPIR 236)? Does Rāmakrșnna's metaphor of the "oneseer pot" that cannot hold "ten seers of milk" only apply to the limitations of human rationality/reason in relation to the infinite ultimate or does it signify a general limitation of human understanding, so that "no mystic is ever justified in limiting God to what they have experienced of Him" (IPIR 236), including Rāmakṛ̣ṇa himself? The answer to this question would determine whether Rāmakṛṣna was a primus-inter-pares pluralist or indeed a "full-blown" pluralist. It would also determine whether he is really so different from Hick as Maharaj claims.

Hick developed his pluralist position by moving from his initial "Copernican" theocentrism (seeing God, instead of one particular religion, at the center of the religious universe) to a position which no longer refers to the central ultimate as a theistic God, nor as a non-theistic Absolute, but as a noumenal Real, which is "in itself" beyond all personal (theistic) or impersonal (non-theistic) categories (beyond form and non-form), but is nevertheless experienced and thought of in the various religions through one of these two categories. Hick describes his move as the avoidance of either theistic or non-theistic inclusivist inclinations. Maharaj, however, sides with a range of critics in judging that Hick thereby established a "Kantian gulf between noumenon and phenomenon" (IPIR 136), which "downgrades the ontological status of the ultimates of the various world religions to phenomenal status" (IPIR 233), and thus "fails to honor the self-understanding of most religious practitioners" (IPIR 7-8). ${ }^{6}$ In contrast, Rāmakṛṣna's model of pluralism would grant "full ontological reality to the personal and the non-personal ultimates of the various religions" (IPIR 8).

This contrast, however, appears strained if we keep in mind that Rāmakṛ̣na, according to Maharaj, understands the personal and impersonal ultimates as different "forms and aspects" of a single Divine Reality (instead of several "ultimates") which in its infinite nature is beyond the range of what humans can experience and which cannot be exhaustively conceptualized by categories such as "personal and impersonal" or "form and non-form." Hick himself never abandoned his talk of the Real as an Infinite Reality, but-as Maharaj is aware-emphasized the apophatic thrust of "in-finity": The ultimate cannot be forced into the finite boundaries of human categories (IPIR 135). Is that not very much in line with Rāmakrṣnạ's metaphor of the one-seer pot that cannot hold ten-seers let alone infinite seers? Contrary to Maharaj's claims, Hick's model does not set up "an ontological gulf between the Real an sich and the various human experiences of the Real" (IPIR 135). ${ }^{7}$ Rather, as Hick himself has emphasized, he uses Kant

\footnotetext{
${ }^{6}$ Moreover, Maharaj regards this as a departure from a Vedānta-inspired concept of the infinite, ignoring that Hick understood infinity as a crucial feature of the divine from a very early stage onwards (see Hick 1988: 189-90, 1963: 6-7, 83).

7 Another major misrepresentation of Hick by Maharaj (again to support the alleged superiority of Rāmakrṣna) is his claim that, in the context of theodicy/eschatology, Hick "presupposes a traditional Christian one-life-only paradigm" (IPIR 298). Unfortunately, Maharaj has taken no notice of Hick's major study Death and Eternal Life (1990). Here, Hick suggests the idea of several lives on different planes or spheres, and in his later writings he increasingly became more hospitable to the possibility of several lives on earth (for example, 1993: 183-96, 1999: 244-52, 2006: 194-200).
} 
"analogously" (!) and in that very special sense in which "the noumenal world exists independently of our perception of it and the phenomenal world is that same world as it appears to our human consciousness" (Hick 1989: 241, 242). The different appearances have much to do with the differences in spiritual practice. If human beings relate themselves to the Real "in the mode of I-Thou encounter, they experience it as personal. Indeed, in the context of that relationship, it is personal, not It but She or He. When human beings relate themselves to the Real in the mode of non-personal awareness they experience it as non-personal, and in the context of this relationship it is non-personal" (Hick 1989: 245; emphasis in the original). ${ }^{8}$ However, the genuine experience of the Real as a personal and a non-personal reality-by means of personal and non-personal concepts-must not belie the fact that ontologically the Real cannot be confined to the limits of what we, through our concepts and categories, can grasp. Hence the Real in itself (= in its infinity) is always infinitely greater.

This is Hick's concept and it is fully consistent—as Hick insists-with a basic tenet affirmed in all the major religious traditions: ultimate reality exceeds essentially and necessarily all our human conceptualizations of it. ${ }^{9}$ Contrary to Maharaj's thesis, Hick's pluralism thus accords with a main feature of the "selfunderstanding of most religious practitioners" (IPIR 8). But it clearly contradicts all those who in a rather modern, self-declared form of orthodoxy, claim that they (or their masters or their "churches") are able to present an adequate concept of God. In the past, personal and non-personal conceptions of the ultimate often come along with a simultaneous awareness of the limitation of all conceptions: "If you understand it, then it is not God" (Augustin, Sermo 117, 3.5; my translation). ${ }^{10}$

This leads me to my third and final point. Maharaj repeatedly emphasizes that Rāmakṛ̣ṇa based his version of religious pluralism on his own practice and experience of other religions, including Islam and Christianity. Only "after following each of these spiritual paths" did he proclaim their epistemic and salvific parity (IPIR 88). ${ }^{11}$ With all due respect, one should not seriously hold that someone has followed Islam or Christianity after having practiced, for three days in 1866, a form of Șūfī $d h i k r$ (being very similar to some forms of Hindu mantra-recitation), and after, again for three days in 1874, conversations about the Bible with a Hindu admirer of Jesus and some Jesus-centered visualization practice. This is not even remotely close to what we find in the practice of so-called dual or multiple belongers. And it can hardly count as a sound foundation on which such a wideranging hypothesis as religious pluralism may be justly based. In contrast, pluralism should be the result of the intense, sustained, and hospitable study of other religious traditions and of an ongoing dialogue with their followers. In that sense it is highly agreeable when Maharaj interprets Rāmakṛṣna’s message as implying "that we can

\footnotetext{
${ }^{8}$ Compare this to Maharaj's claim that Hick "emphatically denies any ontological continuity between the noumenal and the phenomenal" (IPIR 140). In fact, Hick emphasizes exactly the opposite.

9 See Hick 1989: 236-40.

10 The Latin text is available at: https://www.augustinus.it/latino/discorsi/discorso_152_testo.htm. See also Schmidt-Leukel 2017b: 179-87.

11 See also pages $18-19,45,88,116,149,174-75$, and so on, in IPIR.
} 
—and should-actively learn from religions and philosophical worldviews other than our own" (IPIR 99; emphasis in the original), but-hopefully-for more than just three days each.

Funding Open Access funding enabled and organized by Projekt DEAL.

Open Access This article is licensed under a Creative Commons Attribution 4.0 International License, which permits use, sharing, adaptation, distribution and reproduction in any medium or format, as long as you give appropriate credit to the original author(s) and the source, provide a link to the Creative Commons licence, and indicate if changes were made. The images or other third party material in this article are included in the article's Creative Commons licence, unless indicated otherwise in a credit line to the material. If material is not included in the article's Creative Commons licence and your intended use is not permitted by statutory regulation or exceeds the permitted use, you will need to obtain permission directly from the copyright holder. To view a copy of this licence, visit http:// creativecommons.org/licenses/by/4.0/.

\section{References}

Hick, John H. 1963. Philosophy of Religion. Englewood Cliffs: Prentice Hall.

Hick, John. 1988 [1957]. Faith and Knowledge: A Modern Introduction to the Problem of Religious Knowledge. Basingstoke: Macmillan.

Hick, John. 1989. An Interpretation of Religion: Human Responses to the Transcendent. Basingstoke: Macmillan.

Hick, John. 1990 [1976]. Death and Eternal Life. Basingstoke: Macmillan.

Hick, John. 1993. Disputed Questions in Theology and the Philosophy of Religion. Basingstoke: Macmillan.

Hick, John. 1999. The Fifth Dimension: An Exploration of the Spiritual Realm. Oxford: Oneworld Publications.

Hick, John. 2006. The New Frontier of Religion and Science: Religious Experience, Neuroscience and the Transcendent. Basingstoke: Palgrave Macmillan.

Maharaj, Ayon. 2018. Infinite Paths to Infinite Reality: Sri Ramakrishna and Cross-Cultural Philosophy of Religion. New York: Oxford University Press.

Schmidt-Leukel, Perry. 2017a. Religious Pluralism and Interreligious Theology: The Gifford LecturesAn Extended Edition. Maryknoll: Orbis Books.

Schmidt-Leukel, Perry. 2017b. God Beyond Boundaries: A Christian and Pluralist Theology of Religions. Muenster: Waxman.

\section{Publisher's Note}

Springer Nature remains neutral with regard to jurisdictional claims in published maps and institutional affiliations. 